\section{Lionel J. Windsor}

Moore College, Sydney, Australia

Lionel.Windsor@moore.edu.au

ORCID: 0000-0002-2801-4928

\section{Biblica}

et

Patristica

Thoruniensia

11 (2018) 4: 377-390

ISSN (print) 1689-5150

ISSN (online) 2450-7059

\title{
The formation of gentile Christ-believing identity vis-à-vis Israel in Ephesians and Barnabas
}

\author{
Kształtowanie się nieżydowskiej tożsamości \\ wierzących w Chrystusa \\ wobec Izraela w Liście do Efezjan i Liście Barnaby
}

\begin{abstract}
Ephesians is frequently located at a mid-point on a trajectory in early Christianity between Paul's earlier struggles to forge unity between Jewish and gentile Christbelievers and later replacement theologies. The author of the present article tests this trajectory through a comparative analysis of Ephesians and Barnabas, investigating the way in which the two epistles respectively shape a collective memory for their recipients with respect to Israel, its Scriptures and its symbols. Examining the two epistles from this perspective highlights their differences strikingly, calling into question the posited trajectory. In this respect, Ephesians is generally consonant with the undisputed Pauline epistles.
\end{abstract}

Streszczenie. List do Efezjan jest często umieszczany w punkcie środkowym trajektorii wczesnego chrześcijaństwa, między wcześniejszymi zmaganiami Pawła o wypracowanie jedności między żydowskimi i nieżydowskimi chrześcijanami a późniejszymi teologiami zastąpienia. Autor niniejszego artykułu bada tę trajektorię poprzez analizę porównawczą Listu do Efezjan i Listu Barnaby, analizując sposób, w jaki te dwa teksty kształtują pamięć zbiorową swoich odbiorców w odniesieniu do Izraela, jego Pism i symboli. Analiza tych dwóch listów z tej perspektywy podkreśla uderzające różnice, podważając przyjętą trajektorię. Pod tym względem List do Efezjan jest ogólnie rzecz ujmując zgodny z niekwestionowanymi listami Pawłowymi.

Keywords: Ephesians; Barnabas; Israel; replacement theology; collective memory; ethnic identity.

Słowa kluczowe: List do Efezjan; List Barnaby; Izrael; teologia zastąpienia; pamięć zbiorowa; tożsamość etniczna. 


\section{An incipient replacement theology in Ephesians?}

Cphesians is frequently located within a posited trajectory in the ethnic reCasoning of early Christianity. This may broadly be summarised as follows: Stage 1: In the early Christ-believing communities, particularly those within the orbit of Paul's mission, the struggle to forge unity between Jewish and gentile believers was a pressing issue. This struggle gave rise to statements such as those in Romans calling on gentiles humbly to accept their inclusion in Israel's divine benefits, as "wild olive shoots" grafted in among the natural branches (Rom 11:17-24; cf. 1:16; 3:1-2).

Stage 2: In the late first-century Christ-believing communities that were beneficiaries of the success of Paul's mission-e.g. the addressees of Ephesians-the question of intra-communal Jew-gentile unity had become largely theoretical. Consequently, gentile believers began to describe themselves in terms that approached the concept of a new ethnicity that was the true heir to Israel's divine benefits (e.g. Eph 2:11-22).

Stage 3: In the second century and beyond, the concept of Christians belonging to a new ethnicity or a "third race", replacing Israel as the true heir to Israel's divine benefits, became explicit. This replacement theology was often used to deny any legitimacy to ethnic Jews.

Lincoln, for example, writes:

Ephesians has a cool detachment from Jewish Christian/Gentile Christian conflict, and reflects a setting toward the end of the first century when Paul's position on admission of Gentiles had been established, Jerusalem had fallen and Gentile Christians in terms of influence and numbers very much overshadowed any Jewish Christians in the churches of Asia Minor. ${ }^{1}$

Whatever the dangers for the relationship between Christians and Jews which arose from later abuse of the concept, there is no escaping the conclusion that Eph 2 depicts the Church in terms of a new third entity, one which transcends the old ethnic and religious identities of Jew and Gentile. ${ }^{2}$

1 A.T. Lincoln, Ephesians, p. 134.

2 Ibidem, p. 163. 
Lincoln identifies this as an implicit, incipient "third race" concept, though he does not cite any explicit examples of such a concept from early Christian centuries. ${ }^{3}$

Other scholars argue similarly. Dunning claims: "While Ephesians does not use explicitly the language of a third race that became prevalent in second and third century Christian discourse, the logic of the narrative moves in this direction." 4 Talbert argues: "In a predominantly Gentile, Pauline form of Christianity at the end of the first century, one encounters a view of the church as a new humanity, later called a third race." 5

Other scholars, while more circumspect about placing Ephesians on a simple trajectory, nevertheless regard Ephesians as espousing something approaching a "third race" concept. Shkul, exploring Ephesians' "social entrepreneurship" which proceeds through "communal remembering", ${ }^{6}$ regards Eph 2 as differing significantly from Rom 11 with respect to replacement theology:

Romans describes a tree that consists of non-Israelite branches grafted into a cultivated olive tree of Israel, thus maintaining a distinction between the two groups... In contrast, in Ephesians the community likened to a spiritual temple is not constructed of distinct Israelite and foreign components, but of new creations (2.15). ${ }^{7}$

For Shkul, Ephesians' ideology and language "forgets Israel as god's chosen people", "devalue[es] Jewish culture [by] reinterpreting its symbols", "borders on ethnic reasoning where Christianness is imagined as a wholly new entity in comparison to Greeks, Romans and Israel". ${ }^{10}$ Macdonald, who regards the community addressed by Ephesians to be in a "period of fluctuation be-

3 Ibidem, pp. Ixiii, xciii, 134, 144, 276. See W.H. Rader, The Church and Racial Hostility, pp. 228-30, for modern origins of "third race" interpretations of Ephesians.

4 B.H. Dunning, Strangers and Aliens, p. 14. Dunning does not here detail any examples of explicit "third race" terminology from the second or third centuries.

5 C.H. Talbert, Ephesians and Colossians, p. 94. Talbert traces a "trajectory" on pp. 8890 and briefly discusses Justin and Jerome, but only in relation to law-observance. For similar views see J. Gnilka, Der Epheserbrief, s. 139; R.P. Martin, Ephesians, p. 31; E. Best, Ephesians, p. 269; J.A. Harrill, Ethnic Fluidity, pp. 389-401. There are also scholars who accept Pauline authorship of Ephesians yet still see a "third race" concept in Eph 2:11-22, e.g. F.F. Bruce, Epistles, pp. 295-96; H.W. Hoehner, Ephesians, pp. 379-80.

6 These are key terms in M. Shkul, Reading Ephesians, passim, esp. pp. 88-95.

7 Ibidem, p. 90.

8 Ibidem.

9 Ibidem, p. 122.

10 Ibidem, p. 91, n. 35. 
tween Jewish and distinctly 'Christian' identity", believes that "Ephesians just stops short of presenting the church as a 'third race' (Christians)." ${ }^{11}$

Other scholars, however, emphasising such features in Eph 2:11-22 as the

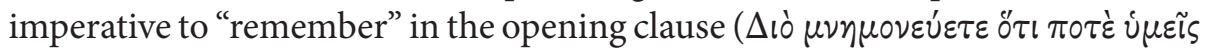

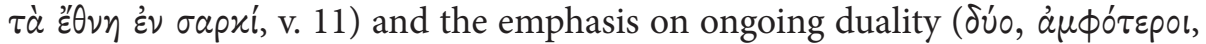
vv. 15-18), argue that Ephesians is deliberately written to ensure that the addressees' prior gentile identity vis-à-vis Israel is not forgotten. Earlier, Barth wrote:

The composition of the "new man out of the two" safeguards the rights of Christians to be different from one another, to "remember" (2:11) their distinct histories, to respect priorities (Rom 3:1-2, 9:4-5), to enjoy unity in diversity (I Cor 12; Eph 4:7, 11-12, 16). ${ }^{12}$

More recently, Fowl has argued:

Here in 2:11 the Ephesians are called to remember their identity as Gentiles... That designation only had currency within Judaism or in relation to Judaism... They need to remember (or reconceive) of their past as a Gentile past. They need to learn both what being a Gentile meant when they were outside of Christ and what it means now that they are in Christ. ${ }^{13}$

For these scholars and others, ${ }^{14}$ Eph 2:11-22 functions quite similarly to Rom 11:17-24, and there is no incipient replacement theology in Ephesians.

\section{Memory construction in Ephesians and Barnabas}

Several points emerge from this discussion. Firstly, the nature and extent of any correlation between Ephesians' theology and later Christian replacement theologies is significant for the overall interpretation of the letter. Secondly, scholarly discussions of the topic frequently proceed without detailed reference to

11 M.Y. MacDonald, Politics of Identity, p. 433; cf. Idem, Colossians and Ephesians, pp. 251-59.

12 M. Barth, Ephesians, pp. 310-11.

13 S.E. Fowl, Ephesians, pp. 85-86.

14 E.g. W.S. Campbell, Unity and Diversity, p. 22; Stenschke, Once You Were in Darkness, pp. 130-31. T.-L.N. Yee, Jews, Gentiles and Ethnic Reconciliation, pp. 72-87, sees strong continuity between Romans and Ephesians in this regard, but regards the command to "remember" in Eph 2:11 primarily as evoking a negative Jewish "ethnocentrism". 
later Christian replacement theologies. Thirdly, a key question in this regard involves what the author of Ephesians wants his addressees to "remember" (and, correspondingly, "forget").

In this article, we will conduct a comparative analysis of Ephesians and the Epistle of Barnabas, exploring the way in which Ephesians and Barnabas respectively shape a collective memory for their recipients with respect to Israel, its Scriptures, and its symbols. ${ }^{15}$ Barnabas provides a useful control for this investigation, since it is an early Christian text espousing an unambiguous replacement theology. ${ }^{16}$ Furthermore, although it is unlikely that the author of Barnabas was familiar with Ephesians, ${ }^{17}$ the two epistles deal with many similar topics and have multiple direct points of comparison.

Esler, writing on the memorialisation of Paul's imprisonment, has provided a useful theoretical framework for exploring collective memory in relation to early Christian texts. ${ }^{18} \mathrm{He}$ observes that: 1 ) collective remembering is central for a group, 2) collective memory is formed through the interpenetration of personally experienced memories and the memories of others in the group, 3 ) the construction of collective memory is a key element of identity-forming processes, and 4) narrative memories in particular can be a key to a person's identity, even when the narrative is not experienced directly by that person. ${ }^{19}$ In light of this framework, we will be asking how Ephesians and Barnabas shape the identity of their communities through constructing a collective memory of their relation to Israel.

For our purposes, it is not necessary to establish the precise occasion for either epistle. Ephesians is general in nature, and there are considerable disagreements over its specific life-setting, provenance and purpose. ${ }^{20}$ Barnabas was written between 70-135 CE, probably in the latter part of this period, possibly in Alexandria, to Christians who were almost certainly gentile (cf. 3.6, 16.7) and who seem to have been attracted to a Jewish way of life and worship. ${ }^{21}$

15 For Ephesians, we will use the critical text in NA28. For Barnabas, we will use the critical text and translation in B.D. Ehrman, Apostolic Fathers, pp. 12-83.

16 Ibidem, p. 3.

17 R. Hvalvik, Struggle for Scripture and Covenant, p. 32.

18 P.F. Esler, Remember My Fetters, drawing from the foundational work of M. Halbwachs.

19 Ibidem, pp. 241-46.

20 For a survey of the issues with respect to these questions, see L.J. Windsor, Reading Ephesians and Colossians, pp. 62-71.

21 B.D. Ehrman, Apostolic Fathers, pp. 6-9. The prospective rebuilding of the temple may have occasioned the letter (S. Lowy, Confutation of Judaism; J.C. Paget, Epistle of Barnabas). 


\section{Narrative memory: Israel's Scriptures}

As noted above, central to the construction of collective memory is the sharing of a narrative. Both Barnabas and Ephesians draw their readers in to a narrative, which formally is the same in each case: the narrative is constituted by the story of Israel as recounted in the Scriptures, quotations of and allusions to which abound in both epistles. ${ }^{22}$ However, as we shall see, the two epistles have substantially different orientations to this scriptural narrative.

\subsection{The "other"}

Social categorization often proceeds by way of contrast with other groups. ${ }^{23}$ One striking way in which Barnabas and Ephesians differ in relation to Israel's Scriptures is their respective delineations of the "other".

In Barnabas, the "other" comprises ethnic Jews. Barnabas frequently distinguishes between Christians and Jews by using a first-person plural personal pronoun to refer to Christians and a third-person plural personal or demonstrative pronoun (the demonstrative emphasising remoteness) to refer to Jews. For example:

watch yourselves now and do not become like some people by piling up your sins, saying that the covenant $(\dot{\eta} \delta 1 \alpha \theta \dot{\eta} x \eta)$ is both theirs ( $\dot{\varepsilon} x \varepsilon \dot{\imath} \nu \omega \nu)$ and ours $(\dot{\eta} \mu \tilde{\omega} \nu)$. For

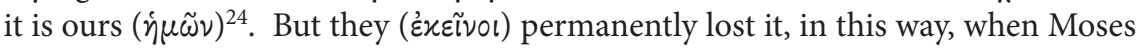
had just received it. (Barn. 4.6-7)

This contrast between "we" and "they"/"those" is a recurring feature of Barnabas' hermeneutical strategy. Scriptural texts that describe wrong approaches to God are assigned to "them"/“those people", while texts describing correct approaches are assigned to "us". ${ }^{25}$ For example, the interpretation of Isa 58:3-10 in Barn. 3.1-5 depicts God as speaking to two different groups: God

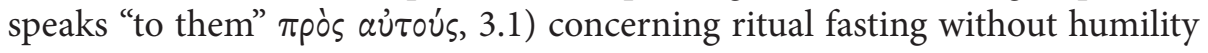

22 E. Mouton, Memory in Search of Dignity, passim; R. Hvalvik, Struggle for Scripture and Covenant, pp. 102-36.

23 Hakola, Social Identities, p. 264.

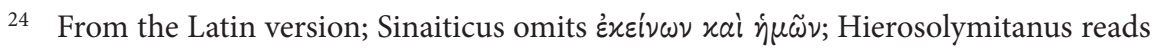

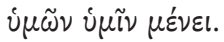

25 S. Lowy, Confutation of Judaism, pp. 1-2. Barn. 5.2 explicitly states this hermeneutical strategy. 
(3.1-2; cf. Isa 58:3-5), but then God speaks "to us" ( $\pi$ pò $\dot{\eta} \mu \tilde{a} \varsigma, 3.3$ ) about true "fasting" which involves justice and care for the poor (3.3-5; cf. Isa 58:6-10). ${ }^{26}$

For Barnabas, Christians rather than Jews are the true heirs of God's covenant with Israel. ${ }^{27}$ Furthermore, as Lowy notes, Barnabas does not use the term "gentile" (or "Jew") at all, since the term assumes an Israelite viewpoint. "The inference is simple: We are now the real Israel. Since the covenant belongs to Christians, the latter are not Gentiles any more." Thus, Christians share in the narrative memory of Israel in contrast with the "Judaean Other". ${ }^{28}$

In Ephesians, however, the "other" is unbelieving gentiles, who represent the former life that the readers once participated in but have now left behind. ${ }^{29}$ A key warning in Ephesians ${ }^{30}$ is not to become like (other) gentiles again:

So I say this and testify in the Lord, that you no longer walk as the gentiles $\left(\tau \dot{\alpha}^{31}\right.$

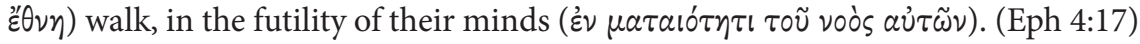

Nevertheless, the believers must still "remember" their former "gentile"

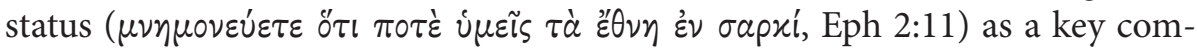
ponent of what they have now become in Christ (cf. 3:1, 6, 8). This command to remember, the first imperatival clause in Ephesians, is in fact a command to adopt an Israel-centred perspective, effectively bringing the readers in to the orbit of Israel's narrative, including "the commonwealth of Israel" ( $\tau \tilde{\eta} \varsigma \pi 0 \lambda i \tau \varepsilon i ́ a \varsigma$

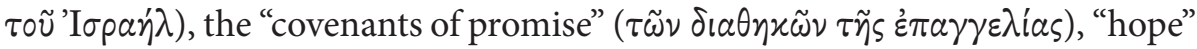
$(\dot{\varepsilon} \lambda \pi i \delta \alpha)$ and "God" (cf. $\alpha \dot{\theta} \varepsilon \circ \iota)$ (Eph 2:12).

Indeed, Ephesians' hermeneutical strategy involves identifying its gentile readers with Israel's "other" - the group who were "far away" before they were made "near":

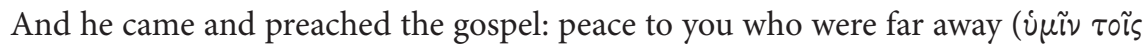

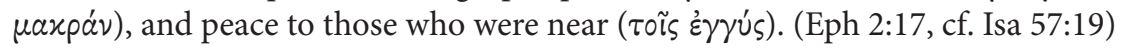

26 For many further examples see Barn. 2.5-10; 5.1-6.19; 8.2; 9.1-6; 10.1-16.10, referring to texts in the Pentateuch, Psalms, Proverbs, Prophets and Apocrypha (see details in B.D. Ehrman, Apostolic Fathers).

27 S. Lowy, Confutation of Judaism, p. 29.

28 M. Kok, True Covenant People, p. 93.

29 W.S. Campbell, Unity and Diversity, p. 16.

30 See further L.J. Windsor, Reading Ephesians and Colossians, p. 197.

31 Several witnesses ( $\aleph^{2}$ D 1 K L P $\Psi$ etc.) insert $\lambda$ or $\pi \dot{\alpha}$ here, presumably to make explicit the implied distinction between these $\mathfrak{\varepsilon}^{\prime} \theta \nu \eta$ and the readers who are Christ-believing $\mathfrak{\varepsilon}^{\prime} \theta \nu \eta$ (cf. $2: 11 ; 3: 1,6,8)$. 
Thus in Ephesians, believing gentiles share in the narrative memory of Israel, not by replacing Jews, but by coming near to Jews. As such, they "must develop a deeper understanding of their links with Israel and thus a more Israelite-related identity". 32

\subsection{Specific texts}

The contrast between the two epistles' hermeneutical strategies is highlighted further when we examine some of those scriptural texts that are referred to by both Barnabas and Ephesians.

Genesis 1:26-28, on the creation of humanity in God's image, is referred to by both epistles. Barn. 6.11-19 uses this text to underscore the fact that Christians, as the new humanity, are the true "heirs of the Lord's covenant" ( $\chi \lambda \eta$ povó $\mu \circ \mathrm{r} \tau \tilde{\eta} s$

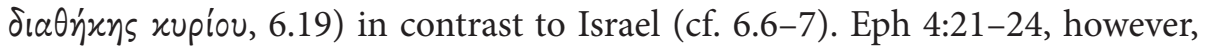
simply uses the text to insist that Christ-believers, as the new humanity, should leave behind their former gentile ways (cf. v. 17).

Isaiah 28:16 and Psalm 118:22, which speak of the precious cornerstone that was rejected by the builders, are also used by both epistles in different ways. Barn. 6.2-4 uses these texts to underscore the hostility between Jesus and the Jews who rejected him (cf. 5.11-12). Eph 2:19-21, by contrast, uses the texts to highlight the privileged status of gentiles who have been included as "fellow citizens of the saints" ( $\sigma \nu \mu \pi 0 \lambda \tilde{\imath} \tau \alpha \iota \tau \tilde{\omega} \nu \dot{\alpha} \gamma i(\omega \nu)$ and "members of God's family"

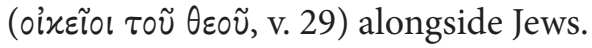

Zechariah 8:16-17, which commands the people of Israel to speak the truth, is also used by both epistles in different ways. Barn. 2.6-8 uses this text to denigrate Jewish sacrifices: it demonstrates the existence of "the new law" ( $\delta$

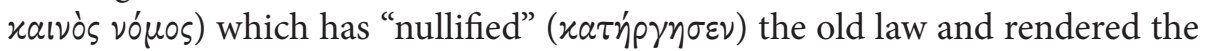
sacrifices invalid (2.6). Eph 4:25 uses the same text, not to denigrate Jewish sacrifice, but simply as an ethical imperative arising from the unity believers share in Christ (ö $\tau \iota \dot{\varepsilon} \sigma \mu \dot{\varepsilon} \nu \dot{a} \lambda \lambda \dot{\gamma} \lambda \omega \nu \mu \dot{\varepsilon} \lambda \eta$, cf. 4:16).

Jeremiah 9:25-26, which indicts Israel for being circumcised only in their flesh and not in their hearts, is also used by both epistles in different ways. Barn. 9.4-6 refers to this text to prove that Jewish circumcision has been "nul-

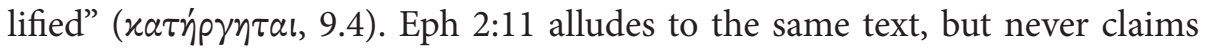
that circumcision has been "nullified". Rather, it simply reminds the readers

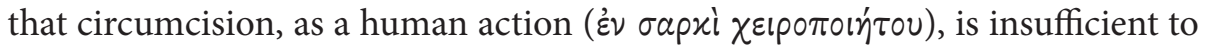

32 W.S. Campbell, Unity and Diversity, p. 24. 
achieve the divine purposes of removing hostility between Jews and Gentiles (cf. 2:13). ${ }^{33}$

\section{Symbolic memory: Israel's symbols}

Another method by which both epistles construct a collective memory is by invoking and applying to their readers the key symbols of Israel: law, sacrifice, inheritance, covenant, temple and people. ${ }^{34}$ While both epistles invoke all of these symbols, they do so in very different ways.

\subsection{Sacrifice}

For both epistles, the death of Christ is described in terms of his "blood", i.e. his sacrificial offering. What did this offering achieve? Both epistles state that Christ's blood primarily achieved the forgiveness of sins:

This is why the Lord allowed his flesh to be given over to corruption, that we might be made holy through the forgiveness of sins ( $\tau \tilde{\eta} \dot{a} \phi \varepsilon ́ \sigma \varepsilon ı ~ \tau \tilde{\omega} \nu \dot{\alpha} \mu a \rho \tau i \tilde{\omega} \nu)$, which

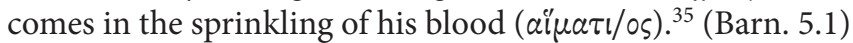

...in whom we have redemption through his blood (ainatos), the forgiveness

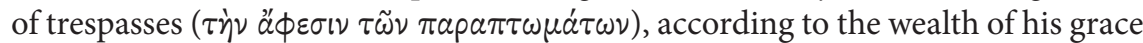
(Eph 1:7)

Yet both Barnabas and Ephesians also describe a second outcome for Jesus' death - and it is at this point that the two epistles differ markedly. For Barnabas, the second outcome is to highlight Israel's sinful hostility to God's purposes:

Therefore, the Son of God came in the flesh for this reason, that he might total

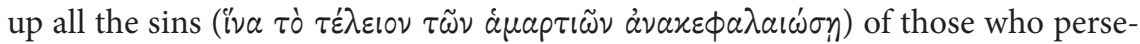
cuted his prophets to death. And so this is why he allowed himself to suffer. (Barn. 5.11-12, cf. 8.2)

Thus, for Barnabas, Jesus' coming accomplishes the division between "those" sinful Jews and "us" Christians who are heirs of the covenant:

33 See further L.J. Windsor, Reading Ephesians and Colossians, pp. 122-24.

34 For these as symbols of Israelite identity see N.T. Wright, Paul and the Faithfulness of God, pp. 354-75.

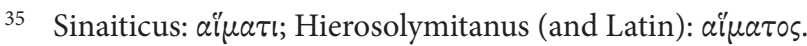


He was made manifest so that those people ( $\chi \dot{\alpha} \chi \varepsilon \tilde{\nu} \nu$ เ) might be completely filled

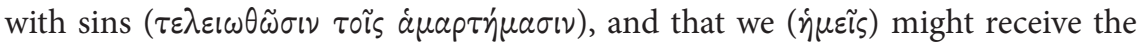

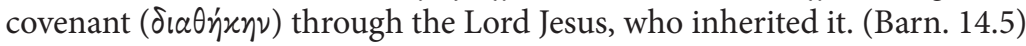

For Ephesians, however, the second outcome of Jesus' blood is described primarily in terms of reconciliation and an end to hostility. All, both Jew and

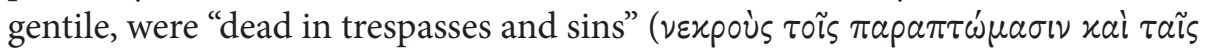
áa $\tau^{\prime}$ 'als, Eph 2:1, cf. v. 3), and so the manifestation of Jesus brings about the reconciliation of "both" to God:

But now in Christ Jesus you who once were far away have been made near by the

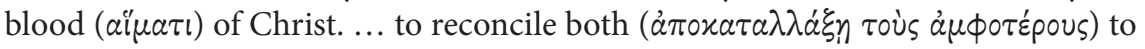

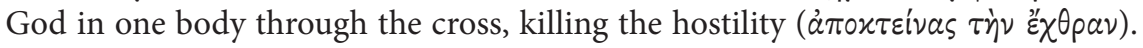

(Eph 2:13, 16)

\subsection{Covenant and inheritance}

Both epistles also evoke Israel's covenant and Israel's inheritance. Barnabas argues that, just as Jacob replaced Esau as the heir to the Abrahamic covenant (Gen 25:21-23) so Christians have replaced Jews in "first" position and heirs to the covenant:

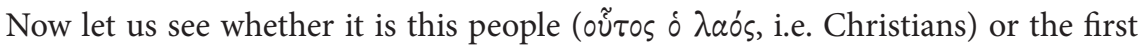
one ( $\dot{\delta} \pi \rho \tilde{\omega} \tau 0$, i.e. Jews) that receives the inheritance ( $\chi \lambda \eta p \circ \nu \circ \mu \varepsilon \tilde{l})$, and whether

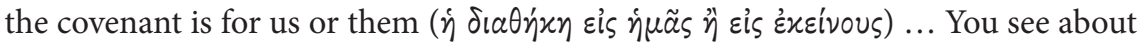

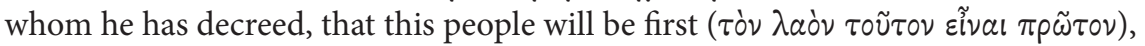

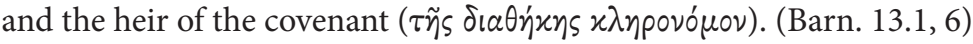

Ephesians, however, has an entirely different understanding of the way Israel's inheritance comes to gentile believers. The foundational Jewish apostolic community is described as "we who have first hoped in Christ" ( $\dot{\eta} \mu \tilde{a} \varsigma . .$.

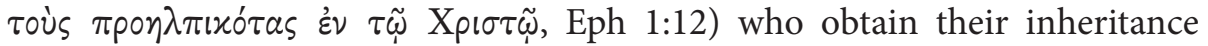
( $\varepsilon x \lambda \eta \rho \omega^{\prime} \theta \eta \mu \varepsilon v$, v. 11). This inheritance is then, through the preaching of the gospel, shared with gentile believers $\left(1: 13-14,18\right.$; 3:6; cf. 5:5). ${ }^{36}$ This presumably includes a share in the benefits of the "covenants of the promise" ( $\tau \tilde{\omega} \nu$ $\delta เ \alpha \theta \eta \kappa \tilde{\omega} \nu \tau \tilde{\eta} \varsigma$ ह่ $\pi \alpha \gamma \gamma \varepsilon \lambda i$ ís) mentioned in 2:12.

36 See further L.J. Windsor, Reading Ephesians and Colossians, pp. 100-107. 


\subsection{Law}

Both Barnabas and Ephesians speak of a "law" (vónos) that is "nullified"

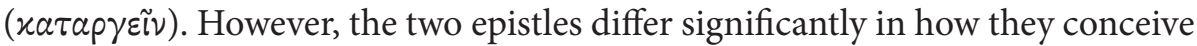
of the nature of the law and its nullification.

For Barnabas, the ritual law of sacrifices (2.4-5) is "nullified" and replaced by a "new" non-sacrificial "law" for Christians:

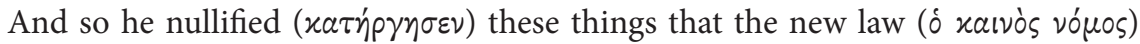
of our Lord Jesus Christ, which is without the yoke of compulsion, should provide an offering not made by humans. (Barn. 2.6)

For Ephesians, however, it is the "law of the commandments in decrees", understood only in its aspect of creating hostility, that is nullified. ${ }^{37}$ The Jewish law is never said to be replaced with a new Christian "law" in Ephesians. Rather, Ephesians states that "hostility" between Jews and gentiles has been replaced with "peace":

For he himself is our peace (Eipท́ $\eta \eta)$, who has made both one and has broken down the dividing wall, the hostility ( $\left.\varepsilon^{\prime} \chi \theta p a v\right)$, in his flesh by nullifying the law of the

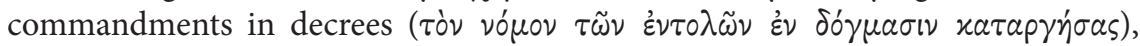
(Eph 2:14-15)

\subsection{Temple}

Both epistles depict Christ-believing community in terms of a spiritual temple in which God dwells. However, they do so for quite different purposes.

When Barnabas speaks of a "spiritual temple built for the Lord" ( $\pi \nu \varepsilon \cup \mu a \tau i x o ̀ s$

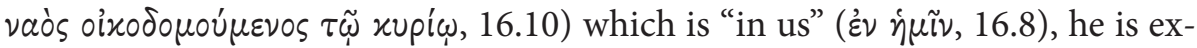
plicitly contrasting it with the physical temple hoped for by "them":

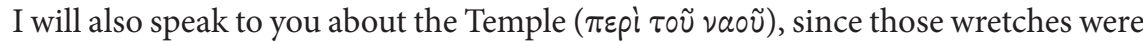
misguided in hoping in the building rather than in their God who made them, as if the Temple were actually the house of God. (Barn. 16.1)

By contrast, Ephesians emphasises the joint share that Jews and gentiles

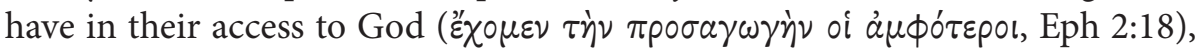
and the universality and harmony of Christ-believing communities as they

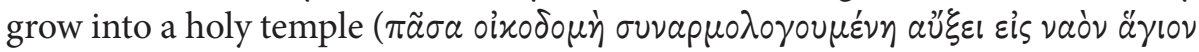

37 See further Ibidem, pp. 134-42. 
E่v xupí, Eph 2:21). Furthermore, Ephesians highlights the fact that the gentile recipients of the letter are being "built together into a dwelling place for God"

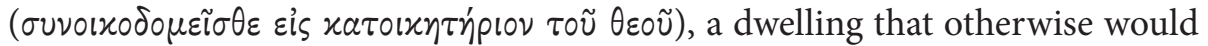
belong to Jews in Christ, but now belongs to "you also" (xai ن́ $\mu \varepsilon i \varsigma$, , Eph 2:22). ${ }^{38}$

\subsection{People}

Finally, we return to the "people" as a key symbol of Israel. For Barnabas, there is a new humanity, consisting of Christians, which explicitly replaces Israel. When discussing the signs and wonders performed in "Israel" (I $\left.\sigma a \eta^{\prime} \lambda\right)$, Barna-

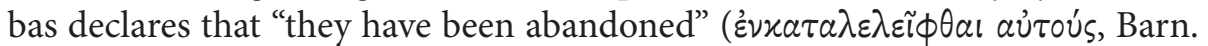
4.14). A short while later (6.13-14), he declares the Lord's word "to us" ( $\pi$ pòs $\dot{\eta} \mu \tilde{a} \varsigma$ ), which forms a contrast with the prophetic word against "Israel" (6.7). The word "to us" concerns a "second formation" ( $\delta \varepsilon v \tau \varepsilon \dot{p} \alpha \nu \pi \lambda \alpha^{\alpha} \sigma \nu$ ), which "has

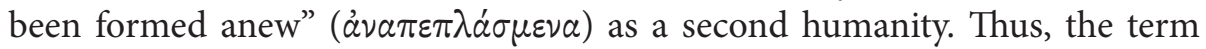
"church" ( $\varepsilon \varkappa \varkappa \lambda \eta \sigma i \alpha)$ describes those whom Jesus blesses and brings in to the kingdom $(6.16 ; 7.11)$, distinct from the "synagogue" ( $\sigma \nu \nu a \gamma \omega \gamma \eta$ ') who put him to death $(5.13 ; 6.6$; cf. Ps 22:16).

For Ephesians, however, the new humanity is comprised of "the two" ( $\tau 0$ is

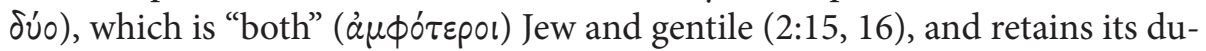

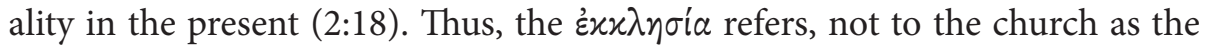
replacement for Israel, but to the united gathering of Jews and gentiles, also called the "body" of Christ (1:22-23, 4:4). ${ }^{39}$

\section{Conclusions}

Barnabas and Ephesians both seek to construct collective memories for their readers by evoking Israel's scriptural narrative and symbols. However, the two epistles differ significantly in the way they construct these memories.

Barnabas contrasts Christians with Jews, adopts a hermeneutical strategy that sees Christians as appropriating all the promises to Israel, depicts Jesus' sacrifice as accomplishing the division between Israel and Christ, regards Jews as having been supplanted by Christians in "first" place, describes the nullification of the law as the end of Jewish ritual, and emphasises the contrast between the new spiritual temple and the physical Jewish temple.

\footnotetext{
38 See further Ibidem, pp. 149-57.

39 See further Ibidem, pp. 143-44.
} 
Ephesians, however, contrasts Christ-believers with their former "gentile" way of life, adopts an Israel-centred hermeneutic that views gentile Christbelievers as graciously included within the promises to Israel, depicts Jesus' sacrifice as an act of reconciliation between gentiles and Jews, regards Jews as retaining their position as "first" in Christ, describes the nullification of the law as the end of hostility between gentiles and Jews, and emphasises the unity of Jew and gentile in the new spiritual temple.

At almost every point, Ephesians and Barnabas differ in the way they describe Christ-believers in relation to Israel, its Scriptures, and its symbols. This calls into question the posited trajectory described at the start of this article. In this regard, Ephesians is quite consonant with the undisputed Pauline letters (e.g. Rom 1:16, 11:17-24). There is no obvious development from Ephesians to the ethnic replacement theologies of the second century and beyond.

\section{Bibliography}

Barth, M., Ephesians, Garden City NY 1974.

Best, E., Ephesians, London 1998.

Bruce, F.F., The Epistles to the Colossians, to Philemon and to the Ephesians, Grand Rapids MI 1984.

Campbell, W. S., Unity and Diversity in the Church: Transformed Identities and the Peace of Christ in Ephesians, Transformation 25/1 (2008), pp. 15-31. DOI: https://doi. org/10.1177/026537880802500102

Dunning, B.H., Strangers and Aliens No Longer: Negotiating Identity and Difference in Ephesians 2, Harvard Theological Review 99/1 (2006), pp. 1-16. DOI: https:// doi.org/10.1017/S001781600600109X

Ehrman, B.D., The Apostolic Fathers Volume II (Loeb Classical Library 25), Cambridge MA 2003.

Esler, P.F., "Remember My Fetters": Memorialisation of Paul's Imprisonment, in: Explaining Christian Origins and Early Judaism: Contributions From Cognitive and Social Science, R. Uro, I. Pyysiäinen, P. Luomanen (eds.), Leiden 2007, pp. 231-58.

Fowl, S.E., Ephesians: A Commentary, Louisville KY 2012.

Gnilka, J., Der Epheserbrief (2nd ed.), Freiburg 1977.

Hakola, R., Social Identities and Group Phenomena in Second Temple Judaism, in: Explaining Christian Origins and Early Judaism: Contributions From Cognitive and Social Science, R. Uro, I. Pyysiäinen, P. Luomanen (eds.), Leiden 2007, pp. 259-76.

Harrill, J.A., Ethnic Fluidity in Ephesians, New Testament Studies 60/3 (2014), pp. 379-402. DOI: https://doi.org/10.1017/S0028688514000046

Hoehner, H.W., Ephesians: An Exegetical Commentary, Grand Rapids MI 2002. 
Hvalvik, R., The Struggle for Scripture and Covenant: The Purpose of the Epistle of Barnabas and Jewish-Christian Competition in the Second Century, Tübingen 1996.

Kok, M., The True Covenant People: Ethnic Reasoning in the Epistle of Barnabas, Studies in Religion 40/1 (2011), pp. 81-97. DOI: https://doi. org/10.1177/0008429810377978

Lincoln, A.T., Ephesians, Dallas TX 1990.

Lowy, S., The Confutation of Judaism in the Epistle of Barnabas, Journal of Jewish Studies 11 (1960), pp. 1-33.

MacDonald, M.Y., Colossians and Ephesians, Collegeville MN 2000.

MacDonald, M.Y., The Politics of Identity in Ephesians, Journal for the Study of the New Testament 26/4 (2004), pp. 419-44. DOI: https://doi. org/10.1177/0142064X0402600403

Martin, R.P., Ephesians, Colossians and Philemon, Louisville KY 1991.

Mouton, E. Memory in Search of Dignity?: Construction of Early Christian Identity through Redescribed Traditional Material in the Letter to the Ephesians, Annali Di Storia Dell'esegesi 29/2 (2012), pp. 133-53.

Paget, J.C., The Epistle of Barnabas: Outlook and Background, Tübingen 1994.

Rader, W.H., The Church and Racial Hostility: A History of Interpretation of Ephesians 2:11-22, Tübingen 1978.

Shkul, M., Reading Ephesians: Exploring Social Entrepreneurship in the Text, London 2009.

Stenschke, C., "Once You Were in Darkness": The Past of the Readers of Ephesians, European Journal of Theology 23/2 (2014), pp. 123-39.

Talbert, C.H., Ephesians and Colossians, Grand Rapids MI 2007.

Windsor, L.J., Reading Ephesians and Colossians After Supersessionism: Christ's Mission through Israel to the Nations, Eugene OR 2017.

Wright, N.T., Paul and the Faithfulness of God, Minneapolis MN 2013.

Yee, T.-L.N. Jews, Gentiles and Ethnic Reconciliation: Paul's Jewish Identity and Ephesians, Cambridge 2004. 